\title{
Kekuatan Hukum Pelekatan Sidik Jari Penghadap Oleh Notaris Pada Minuta Akta
}

\author{
Wulan Wiryanthari Dewi ${ }^{1}$ Ibrahim $\mathbf{R}^{2}$
}

${ }^{1}$ Fakultas Hukum Universitas Udayana, E-mail: wulanwiryantaridewi@gmail.com 2Fakultas Hukum Universitas Udayana, E-mail: mrprof.ibrahim@gmail.com

\begin{tabular}{l}
\hline Info Artikel \\
\hline Masuk: 2 Juli 2020 \\
Diterima:22 September 2020 \\
Terbit:15 Desember 2020 \\
Keywords: \\
Legal Force; Fingerprint; \\
Minuta Deed \\
\\
\\
Kata kunci: \\
Kekuatan Hukum; Sidik Jari; \\
Minuta Akta \\
Corresponding Author: \\
WulanWiryanthariDewi, E- \\
mail: \\
wulanwiryantaridewi@gmail.com \\
10.24843/AC.2020.v05.i03.p01 \\
\\
\end{tabular}

\begin{abstract}
In Article 16 paragraph (1) letter c of Law Number 2 of 2014 stipulates that the Notary is obliged to attach the applicant's fingerprint to the minuta deed, causing a polemic because the provisions do not further regulate if in this case the applicant experiences finger defects or an incident. which results in damage to the fingerprint which makes it unable to affix the fingerprint. The purpose of this research is to find out how the efforts that can be made by the notary against the tappers who are unable to put their fingerprints and the legal consequences of the absence of fingerprints on the strength of the deed. This research is a normative legal research. The results of this study indicate that the efforts that can be made by the notary if there is an attacker who has a finger defect or experiences an event that causes the fingerprint to be damaged so that he cannot attach his fingerprint to the minuta deed, then the notary concerned can explain the matter at the end of the deed made. As a result of the law, there is no attachment of the applicant's fingerprints to the strength of the deed, namely the deed made by the Notary concerned remains an authentic deed even though the fingerprint of the applicant is not attached under Article 1869 of the Civil Code and the deed is valid and legally binding as long as the provisions in Article 1320 of the Civil Code.
\end{abstract}

\begin{tabular}{l}
\hline Abstrak \\
\hline Dalam Pasal 16 ayat (1) huruf c Undang-Undang Nomor 2 \\
Tahun 2014 menentukan bahwa Notaris wajib melekatkan sidik \\
jari penghadap pada minuta akta, sehingga menimbulkan \\
polemik sebab mengenai ketentuan tersebut tidak mengatur lebih \\
lanjutapabiladalam hal ini penghadap mengalami cacatjari atau \\
peristiwa yang mengakibatkan rusaknyasidikjari yang membuat \\
penghadap tidak mampu membubuhkan sidik jarinya. Tujuan \\
penelitian ini ialah untuk mengetahui bagaimana upaya yang \\
dapat dilakukan oleh Notaris terhadap penghadap yang tidak \\
mampu membubuhkan sidik jarinya serta akibat hukum tidak \\
adanya sidikjaripenghadap terhadap kekuatan akta. Penelitian \\
ini termasuk jenis penelitian hukum normatif. Hasil dari \\
penelitianini menunjukan bahwa upaya yang dapat dilakukan \\
oleh Notaris bila terdapatpenghadap yang mengalami cacat jari \\
atau mengalami peristiwa yang menyebabkan rusaknya sidikjari \\
sehingga tidak dapatmelekatkan sidikjarinya pada minuta akta, \\
maka Notaris bersangkutan dapatmenjelaskan mengenai perihal \\
tersebut pada bagianakhir akta yang dibuatnya. Akibat hukum
\end{tabular}


tidakadanyapelekatan sidik jari penghadap terhadap kekuatan akta yaitu akta yang dibuat oleh Notaris yang bersangkutan tetap sebagai akta autentik walaupun tidak dilekatkannya sidik jari penghadap berdasarkan Pasal 1869 KUHPerdata serta akta tersebut berlaku sah dan mengikat secara hukum selama terpenuhinya ketentuan yang termuat dalam Pasal 1320 KUHPerdata.

\section{Pendahuluan}

Manusia sebagai makhluk sosial terbiasa hidup berdampingan sesama manusia dan tidak mampu untuk hidup sendiri. Dalam menjalani kehidupan manusia banyak kebutuhan hidup yang harus dipenuhi sehingga manusia sering melakukan suatu hubungan hukum dengan individu lain. Salah satu hubungan hukum yang dilakukan yaitu dengan mengadakan suatu perjanjian. Sehubungan dengan diadakannya suatu hubungan hukum dengan membuat perjanjian, maka diperlukannya jasa seorang Notaris. Notaris sebagai profesi yang sangat berperan dalam memberi pelayanan jasa bagi masyarakat yang memiliki kepentingan, khususnya dalam hal pembuatan akta autentik. Notaris sebagai pejabat publik yang memiliki wewenang untuk membuat suatu akta secara tertulis yang kepastian hukumnya terjamin. Notaris keberadaannya sangat diperlukan oleh masyarakat yang berkepentingan, dimana masyarakat mengandalkan dan memiliki rasa percaya terhadap Notaris untuk menuangkan segala hal yang diinginkannya kedalam sebuah akta autentik. Notaris membuat akta tidak berdasarkan keinginan diri pribadi, melainkan berdasarkan atas kehendak bebas dari para pihak yang memiliki kepentingan.

Notaris ditugaskan untuk mengkonstatir semua keterangan dan pernyataan yang diberikan kepadanya terkait dengan suatu hal yang dihendaki dan diinginkan oleh para pihak yang berkepentingan. Notaris juga mempunyai kewajiban memberi penyuluhan sehubungan dengan akta yang akan dibuat. Akta yang dibuat mencakup hal-hal terkait semua perbuatan atau perjanjian yang ditugaskan kepada Notaris berdasarkan peraturan perundang-undangan. Notaris yang sedang menjalankan cuti atau telah berakhirnya masa jabatannya tidak diperbolehkan membuat akta. Dalam melaksanakan kewenangannya, seorang Notaris diharuskan menerapkan ketelitian, kehati-hatian dan kecermatan agar masyarakat yang menggunakan jasanya memperoleh perlindungan hukum. Kehadiran Notaris diharapkan dapat memberi rasa aman kepada masyarakat yang memiliki kepentingan untuk melakukan suatu hubungan hukum. Keabsahan tanda tangan pada akta juga akan tetap memiliki kekuatan walaupun Notaris yang bersangkutan diberhentikan ataupun sudah berakhirnya masa jabatan selama pembuatan akta tersebut telah dibuat sebelum adanya pemberhentian atau berakhirnya masa jabatan. Akta autentik sebagai bukti yang menyatakan segala sesuatu yang telah disampaikan oleh penghadap adalah benar. Dalam pelaksanaan membuat akta autentik, Notaris berdasarkan dari permintaan para pihak yang menghadap sesuai kehendak atau keinginan mereka agar kepentingan dan hak mereka dapat terlindungi. Perlindungan tersebut dapat diberikan dengan membuat akta dengan tidak hanya mementingkan salah satu atau sebagian pihak saja. 
Akta notaris yang merupakan akta pihak (partij acta) harus dilakukan penandatanganan akta pada waktu yang bersamaan oleh para penghadapnya dan bila ada yang tidak bisa melakukan tanda tangan harus memberikan alasannya. Penandatangan mempunyai beberapa fungsi, yaitu :1

a. Pernyataan identitas dan kehendaknya

b. Pengakuan telah mengerti dan mengakui kebenaran pernyataannya

c. Mengikat penandatangan

d. Melindungi penandatangan dari ketidaktahuan terhadap isi pernyataan

e. Sebagai penutup dan selesainya pernyataan

Penandatanganan dapat diartikan sebagai pernyataan seseorang bahwa telah menyetujui isi yang tertuang dalam akta. Sebagaimana yang termuat dalam Pasal 1 angka 8 Undang-Undang Jabatan Notaris Nomor 2 Tahun 2014 tentang Perubahan Atas Undang-Undang Nomor 30 Tahun 2004 tentang Jabatan Notaris (selanjutnya disebut UUJN Perubahan) menentukan bahwa minuta akta berisikan tanda tangan para penghadap, saksi, dan Notaris, yang kemudian disimpan sebagai bagian dari Protokol Notaris. Dari ketentuan pasal tersebut, maka penyimpanan minuta akta hanya diwajibkan berisikan tanda tangan. Keabsahan akta notaris dalam hal terdapat keadaan penghadap yang tidak bisa membaca ataupun menulis dapat melakukan perjanjian jika ada pengganti dari tanda tangan yaitu sidik jari dan harus ditegaskan dalam akta keterangan Notaris mengenai hal tersebut. ${ }^{2}$ Namun seiring perkembangannya setelah adanya UUJN Perubahan, sidik jari penghadap menjadi diwajibkan untuk dilekatkan pada minuta akta sesuai ketentuan yang termuat dalam Pasal 16 ayat (1) huruf c UUJN Perubahan.

Setelah diberlakukannya UUJN Perubahan terkait diwajibkannya melekatkan sidik jari para penghadap dalam minuta akta tidak terdengar mudah. Sidik jari biasanya dapat digunakan sebagai pengganti tanda tangan. ${ }^{3}$ Setelah diundangkannya UUJN Perubahan, maka sidik jari penghadap menjadi sesuatu hal yang diwajibkan kepada Notaris meskipun penghadap sudah melakukan penandatanganan pada minuta akta dan jika Notaris tidak melaksanakan kewajibannya akan dikenakan sanksi. Namun pada kenyataannya, pelekatan sidik jari penghadap memunculkan berbagai polemik, sebab ketentuan tersebut tidak mengatur lebih lanjut apabila dalam hal ini penghadap mengalami cacat jari atau peristiwa yang mengakibatkan rusaknya sidik jari yang membuat penghadap tidak mampu untuk membubuhkan sidik jarinya. Oleh karena itu, adanya kekosongan norma yang tidak mengatur lebih lanjut apabila terjadi permasalahan tersebut, maka tujuan penelitian ini ialah untuk mengkaji upaya yang dapat dilakukan oleh Notaris terhadap penghadap yang tidak mampu membubuhkan sidik jarinya, serta akibat hukum tidak adanya pelekatan sidik jari penghadap terhadap kekuatan akta.

\footnotetext{
${ }^{1}$ Budiono, H. (2015). Kumpulan Tulisan Hukum Perdata di Bidang Kenotariatan. Bandung: PT. Citra Aditya Bakti, h. 75-76.

2 Sajadi, I., Saptanti, N., \& Supanto, S. (2015). Tanggung Jawab Notaris Terhadap Keabsahan Akta Notaris Yang Dibuatnya Atas Penghadap Yang Tidak Dapat Membaca dan Menulis, Repertorium, 2(2), h. 181.

3 Suwignyo, H. (2009). Keabsahan Cap Jempol sebagai Pengganti Tanda Tangan dalam Pembuatan Akta Otentik. NOTARIUS, 1(1), h. 68.
} 


\section{Metode Penelitian}

Metode digunakan dalam melakukan suatu penelitian untuk menggali dan mengolah bahan-bahan hukum yang diperoleh untuk menghasilkan sebuah kesimpulan mengenai permasalahan yang dihadapi. Penelitian dapat terselesaikan jika metode yang digunakan sudah sesuai dalam memecah suatu permasalahan yang akan dikaji. Metode penelitian dapat dipastikan dari suatu permasalahan, jika suatu permasalahan yang akan dibahas meneliti peraturan dan norma, maka yang akan dipakai ialah penelitian hukum normatif. Penelitian ini memfokuskan pada kaidah aturan hukum positif, sehingga penelitian ini menggunakan pendekatan undang-undang atau statute approach dan pendekatan konsep atau conceptual approach. Pendekatan ini dilakukan dengan menelaah peraturan perundang-undangan yang sehubungan dengan permasalahan yang akan dikaji. Guna memecahkan suatu permasalahan hukum, maka diperlukan sumber penelitian. Sumber penelitian yang dipergunakan berasal dari bahan hukum primer yaitu peraturan perundang-undangan, sekunder yaitu buku, doktrin serta jurnal, dan tersier. Bahan-bahan tersebut didapatkan dengan studi dokumentasi, lalu dilakukan pengumpulan bahan tersebut dengan cara melakukan pencatatan dengan dipergunakannya sistem kartu, lalu dilakukan analisis secara deskriptif dan sistematisasi.

\section{Hasil Dan Pembahasan}

\subsection{Upaya Yang Dapat Dilakukan Oleh Notaris Terhadap Penghadap Yang Tidak Mampu Membubuhkan Sidik Jari}

Sidik jari memiliki keistimewaan dikarenakan bentuk sidik jari setiap manusia berbeda-beda dan tidaklah mungkin terdapat kesamaan atau kemiripan satu sama lain dan bentuknya pun tidak akan dapat berubah dari lahir sampai mati. Sidik jari dimanfaatkan sebagai identitas diri yang diaplikasikan juga pada Kartu Tanda Penduduk. Sidik jari dapat digunakan untuk membuktikan keaslian identitas seseorang. Penggunaan sidik jari diperlukan juga untuk memastikan identitas penghadap yang mengadakan perjanjian dihadapan Notaris. Hal ini juga lebih memberikan kepastian hukum dibandingkan tanda tangan dikarenakan tanda tangan dapat diubah atau diganti oleh penghadap yang berniat melakukan penipuan. Dalam praktiknya sering terjadi kejadian seperti orang yang hadir dihadapan Notaris bukan orang yang sebenarnya sehingga tanda tangannya pun tidak benar atau palsu. Selain itu terdapat orang yang memiliki itikad buruk sengaja memalsukan tanda tangannya.

Sebagaimana dikemukakan oleh Philipus M. Hadjon, hukum dapat memberi perlindungan bersifat preventif, yakni untuk mencegah terjadinya konflik atau sengketa dan sebagai bentuk sikap hati-hati, serta bersifat refresif yakni untuk menyelesaikan terjadinya konflik atau sengketa karena Notaris sering dipermasalahkan oleh pihak yang melakukan pengingkaran atas isi akta, tanda tangan maupun kehadirannya. ${ }^{4}$ Dengan demikian, sidik jari dapat memberi perlindungan terhadap Notaris dan pihak yang beritikad baik dari niat buruk pihak lain. Hal ini juga sebagai bentuk pencegahan dan antisipasi dari adanya pemalsuan kehadiran penghadap yang tidak sebenarnya. Kebenaran terhadap kehadiran penghadap sangat diperlukan mengingat profesi seorang Notaris sangat mulia dan bermartabat. Masalah

\footnotetext{
${ }^{4}$ Hadjon, P. M. (1987). Perlindungan Hukum BagiRakyat Indonesia. Surabaya: PT. Bina Ilmu, h. 2.
} 
kartu tanda identitas dan dokumen lainnya terkait objek yang akan diperjanjikan harus dilihat dan dicermati sendiri oleh Notaris.

Pasca diberlakukannya UUJN Perubahan mengenai adanya kewajiban Notaris untuk melekatan sidik jari memberikan manfaat untuk memberi bantuan kepada Notaris maupun penghadap yang beritikad baik dalam proses pembuktian di pengadilan bila dikemudian hari terjadi suatu konflik atau sengketa. Hal ini diharapkan dapat dijadikan suatu tindakan preventif agar para pihak tidak ada yang berniat untuk melakukan pemalsuan tanda tangan dan mengingkari tanda tangannya yang dicantumkan dalam minuta akta. Dalam hal ini diperlukan juga kesediaan para penghadap untuk melekatkan sidik jarinya pada saat diminta oleh Notaris. Notaris harus menerapkan pendapat untuk menjelaskan kepada penghadap bahwa penghadap juga harus membubuhkan sidik jari selain tanda tangan. Apabila terdapat penghadap yang tidak bersedia untuk melakukan pembubuhan sidik jarinya, maka Notaris yang bersangkutan harus mampu memberikan penjelasan mengenai fungsi adanya sidik jari sehingga penghadap tidak melakukan penolakan untuk melakukan hal tersebut.

Aturan mengenai diwajibkannya Notaris melekatan sidik jari ini sangatlah penting, karena jika hanya mengandalkan tanda tangan seseorang, tanda tangan tersebut dapat berubah seiring berjalannya waktu dan usia sehingga tidak konsisten, ada kemungkinan karena seseorang tersebut telah mengalami penyakit stroke yang akhirnya mengakibatkan bentuk tanda tangannya tidak lagi sama. ${ }^{5}$ Sedangkan sidik jari sampai kapanpun tidak akan berubah, kecuali jika ada peristiwa tersendiri yang mengakibatkan cacat sementara atau permanen sehingga mengakibatkan rusak khususnya pada jari tangan. Seorang Notaris tidak bertanggung jawab terhadap kebenaran pernyataan maupun dokumen dari penghadap, tetapi Notaris menjamin kebenaran atas tanda tangan dalam minuta akta yang dibuat olehnya, sehingga pelekatan sidik jari dapat digunakan untuk tambahan pembuktian terhadap minuta akta tersebut agar Notaris dan penghadap yang beritikad baik terhindar dari penghadap yang beritikad buruk.

Dalam UUJN Perubahan mengatur sanksi administrasi yang diberikan kepada Notaris yang tidak melaksanakan pelekatan sidik jari para penghadapnya sebagaimana tercantum dalam Pasal 16 Ayat (11) UUJN Perubahan menentukan bahwa Notaris yang tidak melaksanakan kewajiban tersebut, maka dikenakan sanksi berupa :

a. Peringatan tertulis;

b. Pemberhentian sementara;

c. Pemberhentian dengan hormat; atau

d. Pemberhentian dengan tidak hormat.

Sanksi administrasi tersebut diberikan bila tidak melaksanakan kewajiban dan melakukan larangan jabatan ataupun bila melakukan suatu pelanggaran maupun penyimpangan terhadap kewajiban jabatan serta larangan jabatan.

Menurut J. M. Ten Berge, sanksi administratif dibedakan atas :

5 Wibawa, I. B. P. P. (2018). Penggunaan Tanda Tangan Berubah-Ubah oleh Penghadap di dalam Pembuatan Akta Notaris, Acta Comitas: Jurnal Hukum Kenotariatan, 3(3), h. 467. 
a. Sanksi reparatif, yaitu digunakannya sanksi dengan tujuan untuk memperbaiki atas suatu tindakan pelanggaran terhadap aturan hukum.

b. Sanksi punitif, yaitu suatu beban tambahan dan suatu tindakan yang dapat memberi rasa takut terhadap pelanggarnya, dalam hal ini dapat berupa teguran secara tegas.

c. Sanksi regresif, yaitu diartikan sanksi sebagai suatu resiko atau akibat dari ketidakpatuhan terhadap suatu aturan hukum. ${ }^{6}$

Ketidakpatuhan terhadap sesuatu hal yang menjadi kewajiban yang telah diatur dan termuat dalam peraturan perundang-undangan dapat menimbulkan ketidaksesuaian yang tidak diharapkan dari suatu peraturan perundang-undangan tersebut. Sanksi digunakan untuk penegakan suatu aturan yang berisi suatu kewajiban. Sanksi sebagai suatu paksaan dengan tujuan untuk memberi kesadaran terhadap pihak yang melakukan pelanggaran bahwa tindakan yang dilakukannya telah menyimpang dari kaidah hukum yang berlaku sehingga keselarasan suatu aturan hukum akan dapat terjaga. Disamping itu, dapat pula memberi kesadaran serta efek jera kepada pelanggarnya, agar menyadari suatu tindakan yang diperbuatnya telah menyimpang dari peraturan perundang-undangan yang berlaku sehingga akan dapat kembali berbuat sesuai dengan ketentuan yang termuat dalam peraturan itu, serta agar suatu peraturan dapat dilaksanakan dengan baik. Sanksi yang diberikan kepada Notaris berguna sebagai bentuk memberi kesadaran terhadap Notaris bahwa ia telah melakukan suatu penyimpangan dalam melaksanakan tugas jabatannya dan agar Notaris mentaati segala aturan yang telah ditentukan dan ditetapkan didalam peraturan perundang-undangan. Pemberian sanksi juga memberi perlindungan kepada masyarakat yang menggunakan jasanya agar terhindar dari hal-hal yang dapat merugikannya. Bagi Notaris, sanksi dapat bermanfaat dalam menjaga martabat profesi Notaris yang selama ini sebagai profesi yang sangat dipercaya oleh masyarakat yang berkepentingan. ${ }^{7}$ Selain itu, bertujuan untuk melindungi Notaris dari masyarakat yang beritikad buruk yang dapat merugikan. Sanksi juga dapat diartikan sebagai suatu perwujudan tanggung jawab terhadap suatu tindakan yang telah dilakukannya. Secara individu sanksi tersebut sebagai suatu bentuk dari pertanggungjawaban seorang Notaris dalam hal melaksanakan wewenangnya agar masyarakat merasa aman dan yakin membuat akta dihadapan Notaris.

Didalam UUJN Perubahan tidak mengatur mengenai penghadap yang mengalami cacat jari atau mengalami peristiwa yang mengakibatkan rusaknya sidik jari sehingga tidak dapat membubuhkan sidik jarinya. Didalam ilmu hukum untuk mengisi kekosongan hukum, maka salah satu upaya yang dapat dilakukan adalah dengan melakukan konstruksi hukum melalui penafsiran analogis. Penafsiran analogis dapat digunakan untuk penafsiran dari suatu peraturan peundang-undangan dengan cara memperluas pengaturan dalam pasal tersebut. ${ }^{8}$ Adapun penafsiran analogis yang dimaksud dengan melihat ketentuan yang terdapat dalam Pasal 44 UUJN Perubahan yaitu apabila salah satu atau semua penghadap tidak bisa membubuhkan tanda tangannya, maka diharuskan pada bagian akhir atau penutup akta menyebutkan

\footnotetext{
${ }^{6}$ Adjie, H. (2013). Sanksi Perdata dan Administratif Terhadap Notaris Sebagai Pejabat Publik. Bandung: PT. Refika Aditama, h. 106-107.

7 Ibid, h. 90.

${ }^{8}$ Wibawa, I. B. P.P, op.cit, h. 469
} 
alasan terkait kenapa penghadap tersebut tidak bisa membubuhkan tanda tangannya. ${ }^{9}$ Jika didasarkan pada ketentuan tersebut dengan menggunakan penafsiran analogis, maka Notaris dapat menjelaskan mengenai perihal tersebut dalam bagian akhir akta yang dibuatnya bila terdapat penghadap yang mengalami cacat jari atau mengalami peristiwa yang menyebabkan rusaknya sidik jari dikarenakan melekatkan sidik jari penghadap merupakan sebagai suatu tindakan yang diwajibkan oleh Notaris.

\subsection{Akibat Hukum Tidak Adanya Pelekatan Sidik Jari Penghadap Terhadap Kekuatan Akta}

Akta merupakan sebuah pernyataan yang didasarkan atas kehendak yang sengaja dinyatakan secara tertulis dan dibuat oleh para pihak yang memuat isi mengenai hal tertentu yang diinginkannya serta tanda tangannya. Akta dapat dibuat secara tertulis guna memberikan kepastian dan bisa dijadikan alat bukti bila suatu saat terjadi konflik atau sengketa. Akta yang berbentuk tertulis dapat dibuat juga dalam bentuk akta notariil dengan tujuan untuk memperoleh kepastian serta perlindungan hukum. Masyarakat memiliki kepercayaan kepada Notaris untuk menuangkan kehendaknya dalam sebuah akta. Adanya suatu aturan dapat menimbulkan kepastian hukum sehingga adanya ketidaksesuaian terhadap ketentuan yang termuat didalam peraturan peundang-undangan yang mengakibatkan dapat dipermasalahkan mengenai kekuatan atau keabsahan akta tersebut. ${ }^{10}$ Akta autentik digunakan untuk membuktikan mengenai kepastian tanggal dan waktu, kebenaran tanda tangan, serta apa saja yang telah dlihat dan didengar oleh Notaris. Akta autentik memiliki nilai sebagai alat bukti yang sempurna dan bersifat mengikat sehingga bila terdapat sangkalan dari pihak lawan, maka pihak yang melakukan penyangkalan tersebut harus dapat membuktikan sangkalannya dan selama belum adanya bukti yang menyatakan sebaliknya, maka segala sesuatu yang dimuat dalam akta tersebut dianggap benar. ${ }^{11}$ Adapun ketentuan yang mengakibatkan akta notaris menjadi akta dibawah tangan yakni :12

1. Bila melanggar ketentuan Pasal 16 ayat (1) huruf 1 UUJN Perubahan, yaitu tidak membacakan akta dihadapan penghadap dan saksi paling sedikit 2 (dua) orang serta penandatangannya tidak dilakukan pada saat itu juga.

2. Bila melanggar ketentuan Pasal 16 ayat (7) dan ayat (8) UUJN Perubahan, yaitu tidak mencantumkan kalimat bahwa para penghadap menghendaki akta untuk tidak dibacakan.

3. Bila melanggar ketentuan Pasal 39 dan Pasal 40 UUJN Perubahan, yaitu penghadap dan saksi tidak cakap melakukan perbuatan hukum karena belum mencapai usia 18 (delapan belas) tahun atau belum kawin serta mempunyai hubungan perkawinan atau hubungan darah.

4. Bila melanggar ketentuan Pasal 52 UUJN Perubahan, yaitu Notaris membuat akta untuk dirinya maupun orang lain yang memiliki hubungan kekeluargaan

\footnotetext{
${ }^{9}$ Utomo, H. I. W. (2015). Penggunaan SurrogateSebagai Pengganti Tanda Tangan Dalam Akta Notaris Dan Implikasinya Terhadap Kedudukan Akta. J. Huk. Univ. Narotama, h. 11.

${ }^{10}$ Kurniawan, I. W. A. (2018). Tanggung Jawab Notaris Atas Akta yang Tidak Dibacakan Dihadapan Para Penghadap. Acta Comitas: Jurnal Hukum Kenotariatan, 3(3), h. 496.

11 Sitompul, Y.I. (2019). Implikasi Hukum Terhadap Pembuatan Akta Kuasa Menjual Yang Tidak Dilengkapi Dengan Dokumen Asli (Studi Kasus Putusan MajelisPengawas Pusat Nomor 16/ B/MPPN/VII/ 2019), Indonesian Notary, 1(004), h. 14.

${ }^{12}$ Adjie, H. op.cit, h. 95-96.
} 
dengannya, baik yang timbul dari akibat adanya perkawinan maupun hubungan darah.

Secara teoritik tidak dilekatkannya sidik jari penghadap tidak menimbulkan pengaruh apapun terhadap keabsahan atau keautentikan akta Notaris sehingga akta tersebut tetap berlaku sah serta memiliki kekuatan sebagaii alat bukti yang sempurna. ${ }^{13}$ Sebagaimana ketentuan yang termuat dalam Pasal 1869 KUHPerdata yakni akta notaris memiliki kekuatan sebagai akta dibawah tangan bila akta tersebut dibuat dengan ketidakmampuan pejabat umum yang bersangkutan dan mengandung adanya cacat dari segi bentuknya. Cacat dari segi bentuknya dapat berupa tidak dibacakannya akta oleh Notaris yang bersangkutan dihadapan langsung para pihak serta para saksi atau tidak dicantumkannya pada akhir akta mengenai dibacakan atau tidak dibacakan akta tersebut. Selain itu, cacat dari segi bentuknya dapat dilihat dari cakapnya para pihak dalam bertindak. Dalam melakukan hal membuat akta, Notaris juga tidak terlepas dari ketentuan mengenai syarat yang menentukan suatu perjanjian dapat dikatakan sah atau tidak. Keabsahan ini didasarkan atas ketntuan dalam Pasal 1320 KUHPerdata. Pasal tersebut mensyaratkan dalam membuat perjanjian harus didasari kata sepakat para pihak, cakapnya bertindak para pihak, terdapat sesuatu hal tertentu, serta memuat kausa atau sebab yang halal atau tidak terlarang. Kesepakatan yang dimaksud harus timbul dari hati nurani para pihak tanpa terdapat unsur paksaan dari pihak lain dan penipuan. Cakapnya seseorang juga harus diperhatikan serta kewenangannya dalam bertindak, seperti halnya dalam menjual atau membebankan tanah maupun bangunan yang diperoleh dalam masa berlangsungnya perkawinan yang menjadikan harta kekayaan bersama harus dengan persetujuan pasangan kawin terlebih dahulu, lain halnya bila sudah ada perjanjian kawin atau pisah harta, maka tidak diperlukan persetujuan pasangan. Suatu hal tertentu sehubungan dengan yang dijadikan obyek dalam akta tersebut, dimana dalam hal ini obyek tersebut harus tidak atau sedang dalam suatu sengketa. Memuat kuasa yang halal berkaitan dengan akta tersebut dilarang atau tidak diperbolehkan brtentangan dengan aturan hukum, kepatutan, ketertiban umum serta kesusilaan. Apabila syarat tersebut telah dipenuhi, maka akta Notaris akan tetap sah dan memiliki nilai kekuatan sebagai akta autentik.

Berdasarkan teori perjanjian tersebut, maka dilekatkannya atau tidak sidik jari penghdap dalam minuta akta yang ditentukan oleh UUJN Perubahan tidak sebagai suatu tindakan yang memberi pengaruh terhadap keabsahan atau keautentikan akta Notaris karena tidak terdapat pula pasal yang mengatur demikian, melainkan hanya sebagai jaminan kebenaran kehadiran penghadap dihadapan Notaris agar penghadap tidak bisa mengingkari tanda tangannya. Dengan demikian tidak adanya pelekatan sidik jari penghadap pada minuta akta tidak menyebabkan akta autentik memiliki kekuatan sebagai akta dibawah tangan. Notaris yang tidak menjalankan kewajiban tersebut karena adanya cacat jari atau rusaknya sidik jari penghadap tidak memberi pengaruh terhadap keabsahan atau keautentikan akta Notaris yang bersangkutan sehingga tetap sebagai akta autentik.

${ }_{13}$ Adjie, H. (2017). Penafsiran Tematik Hukum Notaris Indonesia Berdasarkan Undang-Undang Nomor 30 Tahun 2004 Tentang Jabatan Notaris. Bandung: PT. Refika Aditama, h. 25. 


\section{Kesimpulan}

Sidik jari penghadap diperlukan meskipun telah dibubuhkannya tanda tangan dalam minuta akta. Sidik jari penghadap dapat memberi manfaat yakni memberi perlindungan kepada Notaris yang bisa dijadikan bukti tambahan mengenai identitas penghadap dan keadaan penghadap yang memang benar telah hadir berhadapan agar mengantisipasi bila suatu saat ada penghadap yang memungkiri tanda tangannya pada minuta akta. Sidik jari untuk menjamin kepastian serta perlindungan hukum agar Notaris dan penghadap yang memiliki itikad baik dapat terlindungi dari penghadap yang memiliki itikad buruk. Dalam hal terdapat penghadap yang mengalami cacat jari atau mengalami peristiwa yang mengakibatkan rusaknya sidik jari sehingga tidak dapat membubuhkan sidik jarinya, maka Notaris dapat melakukan upaya dengan cara menjelaskan perihal tersebut pada bagian akhir akta bersangkutan karena melekatkan sidik jari merupakan suatu tindakan yang diwajibkan dan harus dilaksanakan oleh Notaris yang dapat memberikan sanksi administrasi. Akibat hukum tidak adanya sidik jari penghdap pada minuta akta karena tidak mampunya penghadap membubuhkan sidik jarinya tidak menyebabkan hilangnya keautentikan suatu akta. Akta tersebut tetap memiliki kekuatan sebagai akta autentik sepanjang dibuat oleh dihadapan Notaris yang berwenang dan tidak mengandung cacat dari segi bentuknya sebagaimana ketentuan dalam Pasal 1869 KUHPerdata. Akta tersebut juga tetap sah mengikat secara hukum selama telah terpenuhinya ketentuan dalam Pasal 1320 KUHPerdata.

\section{Daftar Pustaka / Daftar Referensi}

\section{$\underline{\text { Buku }}$}

Adjie, H. (2013). Sanksi Perdata dan Administratif Terhadap Notaris Sebagai Pejabat Publik. Bandung: PT. Refika Aditama.

. (2017). Penafsiran Tematik Hukum Notaris Indonesia Berdasarkan UndangUndang Nomor 30 Tahun 2004 Tentang Jabatan Notaris. Bandung: PT. Refika Aditama.

Budiono, H. (2015). Kumpulan Tulisan Hukum Perdata di Bidang Kenotariatan. Bandung: PT. Citra Aditya Bakti.

Hadjon, P. M. (1987). Perlindungan Hukum Bagi Rakyat Indonesia. Surabaya: PT. Bina Ilmu.

\section{Jurnal}

Kurniawan, I. W. A. (2018). Tanggung Jawab Notaris Atas Akta yang Tidak Dibacakan Dihadapan Para Penghadap. Acta Comitas: Jurnal Hukum Kenotariatan, 3(3).

Sajadi, I., Saptanti, N., \& Supanto, S. (2015). Tanggung Jawab Notaris Terhadap Keabsahan Akta Notaris Yang Dibuatnya Atas Penghadap Yang Tidak Dapat Membaca dan Menulis, Repertorium, 2(2). 
Suwignyo, H. (2009). Keabsahan Cap Jempol sebagai Pengganti Tanda Tangan dalam Pembuatan Akta Otentik. NOTARIUS, 1(1), 63-74.

Sitompul, Y. I. (2019). Implikasi Hukum Terhadap Pembuatan Akta Kuasa Menjual Yang Tidak Dilengkapi Dengan Dokumen Asli (Studi Kasus Putusan Majelis Pengawas Pusat Nomor 16/B/MPPN/VII/2019), Indonesian Notary, 1(004).

Utomo, H. I. W. (2015). Penggunaan Surrogate Sebagai Pengganti Tanda Tangan Dalam Akta Notaris Dan Implikasinya Terhadap Kedudukan Akta. J. Huk. Univ. Narotama, 1-16.

Wibawa, I. B. P. P. (2018). Penggunaan Tanda Tangan Berubah-Ubah oleh Penghadap di dalam Pembuatan Akta Notaris, Acta Comitas: Jurnal Hukum Kenotariatan, 3(3).

\section{$\underline{\text { Peraturan Perundang-undangan }}$}

Kitab Undang-Undang Hukum Perdata

Undang-Undang Republik Indonesia Nomor 2 Tahun 2014 tentang Perubahan Atas Undang-Undang Nomor 30 Tahun 2004 tentang Jabatan Notaris, Lembaran Negara Republik Indonesia Tahun 2014 Nomor 3, Tambahan Lembaran Negara Republik Indonesia Nomor 5491. 